\title{
РАЗДЕЛІІ. БИОЛОГИЯ
}

\author{
Лепилина А.С., Кудашкина Н.П. \\ Особенности взаимоотношений сочленов желудочно-кишечного тракта крупного \\ рогатого скота \\ Кемеровский государственный медииинский университет \\ (Россия, Кемерово)
}

doi:10.18411/spc-15-04-2018-17

idsp: 000001:spc-15-04-2018-17

\section{Abstract}

The article is devoted to the issues of the parasites' interaction "bacteria-protozoahelminths" in the joint parasitization in the gastrointestinal tract of cattle on the basis of the peculiarities of their localization and physiology. On the basis of the data studied, the conclusion is drawn that parasitism is a nonnegative interspecific relationship for the host organism.

Цель исследования - изучение особенностей взаимоотношений в системе «бактерии-простейшие-гельминты» при совместном паразитировании в желудочнокишечном тракте жвачных.

Материалы исследования: изучены и проанализированы научные статьи российских и зарубежных учёных на тему взаимоотношений паразитов разных таксономических групп в организме хозяина.

Результаты и их обсуждение. Население желудочно-кишечного тракта КРС представлено разнообразием видов вирусов, бактерий, простейших и гельминтов и находится во взаимоотношениях между собой, с хозяином и внешней средой. Среди этих организмов выделяют три устойчивых типа взаимоотношений: синергизм, антагонизм, антибиоз, при этом формирование подобных отношений осуществлялось на протяжении долгого периода [7].

Наиболее заселенным отделом желудка жвачных является рубец, первый отдел желудка, $\mathrm{pH}$ в котором является оптимальным для жизни многих организмов. Именно здесь прослеживается синергизм между сочленами конгломерата таксономически различных микробов, включающий в себя около 150 видов бактерий, 100 видов реснитчатых и равнореснитчатых инфузорий, 80 видов грибков.Это гнилостные, маслянокислые микробы, энтерококки, стафилококки, диплококки, бактериофаги, дрожжи, плесени, актиномицеты, изотрихиды, энтодинии, эпидинии, стрептококки и др. [5].

Каждый из сочленов конгломерата выполняет свою взаимозависимую функцию в нормальном пищеварении в рубце: ферментируют целлюлазу для расщепления клетчатки, сбраживают сахара, синтезируют гликоген, аминокислоты, витамины группы В.

Например, инфузории р. Entodinium и р. Diplodinium вырабатывают незаменимые аминокислоты и протеины, способны сами переваривать целлюлозу, при этом клетчатка не является в их питании незаменимым углеводом. Польза очевидна: жвачным бактерии нужны как незаменимый источник азота, а также продуктов дегидратации целлюлозы $[2,9,11]$. 
Однако, находясь в синергетических отношениях с макроорганизмом, часто сочлены когломерата являются антагонистами. Ресничных простейших условно делят на два типа: А и Б. Тип А включает Polyplastron multivesiculatum, Diploplastron affine, Ophryoscolex tricoronatus; к типу Б отнесеныEudiplodinium maggii, Epidinium, Eremoplastron, Ostracodinium. Популяция простейших типа А необратимо устраняет из фауны рубца инфузории типа Б. Основные причины антагонизма - конкуренция различных видов за источники питания. Так, P.multivesiculatum является высокоспецифичной плотоядной инфузорией, поедающей инфузорий различных родов, меньших ее по размеру.

Антагонизм отмечен в отношениях между бактериями и простейшими. В рубце дефаунизированных животных, популяция бактерий увеличивается, и наоборот, она уменьшается после введения простейших в рубец через фистулу или другим путем. В присутствии Entodinium численность бактерий в рубце снизилась до 35-40×10 мл. Bolyplastron также сдерживали размножение бактерий, количество которых через 3-4 ч после кормления не превышало 21-24×109 мл [6].

Антагонизм прослеживается и в отношениях макроорганизма с его естественной микрофлорой (стрептококками, стафилококками и эшерихиями и др.). В малых количествах они не наносят вреда организму, образуют экзотоксины (гемолизин, лейкоцидин), продуцируют ферменты (гиалуронидаза, фибринолизин, ДНК-азу и др.), и термостабильные эндотоксины. При заражении кишечными инвазиями, например, стронгилоидной, численность бактерий возрастает. Если иммунитет животного не справляется, они вызывают гнойно-воспалительные процессы кишечного тракта, диарею, что наносит непоправимый вред здоровью животного и часто приводит к гибели [4].

При совместном паразитировании гельминтов M.expansa и M.benedeni встречается антибиоз, который выражается в выработке веществ, вредно действующих на конкурирующих особей, что приводит к изменению размеров тела, разному созреванию гермафродитных и зрелых члеников [1].

При совместном паразитировании трихоцефа и эзофагостом, значительно снижается плотность популяции отдельных видов нематод по сравнению с инвазией, вызванной отдельными видами. Но при этом размеры трихоцефал и эзофагостом при смешанной инвазии существенно не отличаются от размеров этих видов нематод при отдельном паразитировании[8].

Заключение.Все взаимоотношения организмов в природе имеют положительные последствия, эволюция не создает однозначно отрицательные контакты между видами. Паразиты на уровне популяции и индивидуума, осуществляя «вредоносную» функцию у хозяина, одновременно стимулирует его иммунную систему, которая в совокупности с неспецифическими факторами резистентности обеспечивает охрану гомеостаза организма [10].

$$
* * *
$$

1. Белиев С-М.M., Атаев А.М. Влияние интенсивности инвазии на размеры тела Monieza Expansa (Rud., 1810) и Monieza Benedeni (Moniez, 1879)// Теория и практика паразитарных болезней животных. 2011. №1. С.58-59.

2. Догель В.А. Новые перспективы в изучении процессов пищеварения жвачных животных [Текст] / В.А. Догель // Известия Гос. Института Опытной Агрономии. - 1925. - Т. 6, № 5-6. - С. 122-127.

3. Иванкова А.А. Распределение и численность инфузорий в разных отделах желудка быка домашнего (Bos taurus) из агрохозяйств юга тюменской области // Известия Самарского научного центра Российской академии наук. 2010. Том 12. №1(8). С. 2037-2040. 
4. Катков А.Е., Романова Е.М. Особенности микробиоценоза кишечника на фоне стронгилоидной инвазии // Вестник Ульяновской государственной сельскохозяйственной академии. 2007. С.61-66

5. Лепилина А.С., Кудашкина Н.П. Бактерии, простейшие и гельминты - как сочлены паразитоценоза желудка жвачных // Тенденции развития науки и образования. - 2017. С.36-38.

6. Максимюк Н.Н., Скопичев В.Г. Физиология кормления животных // Учебник. - С. ПетербургМосква-Краснодар, 2004. С.94-103.

7. Маниковская Н.С., Новаковская В.В. Эволюционные перспективы живых систем на примере взаимоотношений трематоды Gastrothylax crumenifer и крупного рогатого скота // Животный мир Казахстана и сопредельных территорий. - Алматы, 2012. - С. 139-140.

8. РадионовА.В., Архипов.И.А. Межвидовые отношения Trichocephalus ovis и Oesophagostomum radiatum в кишечнике крупного рогатого скота//Российский паразитологический журнал. 2012 . №1. C.70-73.

9. Рябиков А.Я., Октябрев Н.М. Пищеварение в рубце бычков черно-пестрой породы в 6-месячном возрасте // Омский научный вестник. 2012. №1 (108). С.129-132.

10. Тетиор А.Н. Человек и природа: антибиоз // Wschodnioeuropejskie Czasopismo Naukowe. 2015. Tом 2. № 2. C. 157-164.

11. Чёрная Л.В. Особенности питания эндобионтных инфузорий // Международный журнал прикладных и фундаментальных исследований. 2015. № 4-2. С.233-237. 